\title{
HUBUNGAN KADAR TROMBOSIT DAN KEJADIAN KAKI DIABETIK PADA PENDERITA DIABETES MELITUS TIPE 2
}

\author{
${ }^{1}$ Nursina D. Puspita \\ ${ }^{2}$ Yuanita A. Langi \\ ${ }^{2}$ Linda W. A. Rotty \\ ${ }^{1}$ Kandidat Skripsi Fakultas Kedokteran Universitas Sam Ratulangi Manado \\ ${ }^{2}$ Bagian Penyakit Dalam Fakultas Kedokteran Sam Ratulangi Manado \\ Email: nursinapuspita@yahoo.co.id
}

\begin{abstract}
Diabetes mellitus is characterized with hyperglycemia that occurs due to abnormal secretion of insulin, abnormal function of insulin, or both. It is a metabolic disorder that genetic and clinic heterogeneous with manifestation including loss of carbohydrate tolerance. Diabetes mellitus is characterized by fasting hyperglycemia, postprandial hyperglycemia, atherosclerosis, and neuropathy. Diabetic foot is one of the chronic complications related to macroangiopathy, microangiopathy, and neuropathy. In diabetes mellitus suspected platelets disfunction occurs in patients with diabetes mellitus. This research is observational analytic with design of case control. Subjects of the study is a patients with diabetes mellitus type 2 and complications diabetic foot and without the complications diabetic foot is treated at poly endocrine, poly foot at hospital BLU/RSUP. Prof. Dr. R. D. Kandou Manado. Statistical evaluation was performed by SPSS, normality data test using Kolmogorov-Smirnov, analyzed with Mann Whitney U-test and the correlation analysis using Spearman Correlation Test. The result normality test for the case group Kolmogorov-Smirnov test value $\mathrm{p}=0.715$, as for the control group $\mathrm{p}=0.455$ distribution is normal. And the result analyzed Mann Whitney U-test value $p=0.017$. The calculation of the Spearman correlation test value $p=0.015$ and coefficient $=-0.381$. In this study conclude that platelets count in the normal range but there are differences in average of number of platelets both group, the group with diabetic foot were higher compared to the group non diabetic ulcer. The average number of platelets in group with diabetic foot was higher which indicated that could be either the cause or the due effect of the vascular complications. Platelets may play a role and can be used as a simple parameter to assess the vascular in diabetes.
\end{abstract}

Keywords: trombosit platelets, diabetes mellitus, diabetic foot

\begin{abstract}
Abstrak: Diabetes melitus merupakan penyakit metabolik dengan karakteristik hiperglikemia yang terjadi karena kelainan sekresi insulin, kerja insulin atau kedua-duanya. Gangguan metabolisme terjadi secara genetik dan klinis termasuk heterogen dengan manifestasi hilangnya toleransi karbohidrat. Penyakit ini ditandai dengan hiperglikemi puasa dan potstprandial, aterosklerosis, dan neuropati. Kaki diabetik merupakan penyakit vaskular mikroangiopati dan salah satu komplikasi kronik utama diabetes melitus yang terkait makroangiopati, mikroangiopati, neuropati. Pada diabetes melitus diduga terjadi disfungsi trombosit. enis penelitian ini ialah analitik observational dengan disain case control. Subyek penelitian ialah penderita diabetes mellitus tipe 2 dengan komplikasi kaki diabetik dan yang tidak dengan komplikasi kaki diabetik yang berobat di poli endokrin penyakit dalam dan poli kaki BLU/RSUP. Prof. Dr. R. D. Kandou Manado. Pengolaan evaluasi data ini menggunakan SPSS dengan uji normalitas data menggunakan Kolmogorov-Smirnov yang dianalisis dengan Mann Whitney U-test dan untuk korelasinya dianalisis menggunakan Spearman Correlation test. Hasil uji normalitas kelompok kasus nilai $\mathrm{p}=0,715$, untuk kelompok kontrol $\mathrm{p}=0,455$ yang berarti berdistribusi normal. Hasil statistik Mann Whitney U-test nilai $\mathrm{p}=0,017$. Perhitungan
\end{abstract}


statistik dengan Spearman Correlation test menunjukkan hasil p=0,015 dan koefisien -0,381. Dalam penelitian ini jumlah trombosit dalam batas normal tetapi terdapat perbedaan rerata angka trombosit kedua kelompok dimana pada kelompok dengan kaki diabetik lebih tinggi dari pada kelompok diabetes melitus tanpa ulkus diabetik. Hal ini menunjukkan bahwa meningkatnya rerata angka trombosit bisa menjadi salah satu penyebab atau efek dari komplikasi vaskular. Oleh karena itu trombosit mungkin berperan dan dapat digunakan sebagai parameter sederhana untuk menilai pembuluh darah pada diabetes.

Kata kunci: angka trombosit, diabetes melitus, kaki diabetik

Diabetes melitus ( DM ) adalah gangguan metabolisme yang ditandai dengan menurunnya kemampuan atau hilangnya toleransi karbohidrat. Karbohidrat dicerna dan diproses di dalam sel tubuh menjadi glukosa, insulin merupakan hormon yang menurunkan glukosa darah, dihasilkan oleh sel-sel beta pankreas yang dibutuhkan untuk memasukkan glukosa dari darah ke dalam sel. Pada penderita diabetes mellitus, insulin yang dihasilkan tidak memadai untuk membawa glukosa ke dalam sel sehingga glukosa terkumpul di dalam darah, dan menyebabkan timbulnya gejala diabetes mellitus. ${ }^{1}$ Menurut WHO akan terjadi kenaikan jumlah penyandang diabetes melitus di Indonesia dari 8,4 juta pada tahun 2000 menjadi sekitar 21,3 juta pada tahun 2030. Menurut International Diabetes Federation (IDF) pada tahun 2009, jumlah penyandang diabetes melitus tahun 2009 dari 7,0 juta menjadi 12,0 juta di tahun 2030.

Berdasarkan data Badan Pusat Statistik Indonesia (2003) diperkirakan penduduk Indonesia yang berusia diatas 20 tahun sebesar 133 juta jiwa, dengan prevalensi diabetes melitus pada daerah perkotaan sebesar $14,7 \%$ dan daerah pedesaan sebesar 7,2\%. Laporan dari hasil Riset Kesehatan Dasar (Riskesdas) tahun 2007 oleh Departemen Kesehatan, menunjukkan prevalensi diabetes melitus di daerah urban Indonesia untuk usia di atas 15 tahun sebesar 5,7\%, dan untuk usia di atas 20 tahun prevalensi di daerah perkotaan $(14,7 \%)$ dan perdesaan (7,2\%) maka diperkirakan nantinya terdapat 12 juta penyandang diabetes di daerah perkotaan dan 8,1 juta di daerah perdesaan. ${ }^{2}$ Diabetes tipe II di Indonesia berkisar antara 1,4 sampai 1,6\%, kecuali di Pekajangan desa dekat Semarang sekitar 2,3\% dan Manado 6\%. Di Pekajangan prevalensi agak tinggi diduga dikarenakan banyaknya perkawinan antar kerabat, sedangkan di Manado diduga prevalensi agak tinggi karena letak geografisnya yang berdekatan dengan Filipina, karena prevalensi diabetes di Filipina di daerah urban sekitar 8,4\% sampai $12 \%$ dan 3,85 sampai 9,7\% di daerah rural. $^{3}$

Kaki diabetik adalah salah satu bentuk komplikasi kronik umum dari diabetes melitus tipe II yang sering terjadi di kaki. Di RSUPN dr. Cipto Mangunkusumo, kaki diabetik masih termasuk masalah besar bagi sebagian besar perawatan penyandang DM. Angka kematian dan amputasi masih tinggi, masing-masing sebesar $16 \%$ dan 25\% (data RSUPNCM tahun 2003). Tingkat prevalensi dari diabetes melitus tipe II meninggal karena kaki diabetik sebanyak 14,3\% akan meninggal dalam setahun pasca amputasi, dan akan meninggal sekitar $37 \%$ setelah tiga tahun pasca amputasi. ${ }^{4}$ Setiap tahun lebih dari satu juta kasus penderita diabetes mengalami komplikasi kaki diabetes dan kehilangan salah satu tungkai bawah. Ini berarti setiap 30 detik penderita diabetes dengan komplikasi kaki diabetik kehilangan kakinya. Dan dari semua amputasi tungkai bawah 40-70\% dikarenakan diabetes. 6-8/1000 orang penderita diabetes dengan didahului ulkus kaki berakhir dengan amputasi. ${ }^{5}$

Pada penderita diabetes melitus tipe II terjadi trombosit arteri dimana terdapat keruskan endotel yang akan diikuti dengan aktivasi trombosit dan sistem pembekuan. Trombosis arteri sering terjadi di daerah 
percabangan, karena terjadi perubahan aliran darah yang mengakibatkan terjadinya kerusakan endotel, yang menyebabkan sifat non trombogenik sehingga terjadi aktivasi trombosit dan dan sistem pembekuan darah yang akhirnya menjadi thrombus. ${ }^{6}$ Keadaan inilah yang terjadi pada pasien diabetes mellitus tipe II dengan kaki diabetik.

\section{METODE PENELITIAN}

Desain penelitian ini merupakan analitik observasional dengan case control dimana kelompok kasus dibandingkan dengan kelompok kontrol berdasarkan status keterpaparannya. Penelitian dilaksanakan mulai dari bulan November 2012 sampai akhir bulan November 2012 di BLU/RSUP. Prof. Dr. R. D. Kandou di Poli Endokrin, Poli Kaki, dan laboratorium prokita. Kriteria inklusi pada kelompok kasus adalah penderita diabetes melitus dengan kaki diabetik yang sudah terdiagnosis dan kontrol di poli kaki, sedangkan kriterian inklusi kelompok kontrol penderita diabetes melitus tipe II tanpa kaki diabetik. Kriteria eksklusi adalah penderita diabetes melitus tipe II yang menderita penyakit jantung koroner, gagal ginjal, hipertensi, merokok, dan subjek menolak untuk berpartisipasi. Variabel bebas adalah angka trombosit, variabel terikat adalah kejadian kaki diabetik dengan diabetes melitus tipe II. Dalam melaksanakan penelitian ini, beberapa langkah yang perlu dilakukan diantaranya alokasi subjek dan pengumpulan data hasil laboratorium kadar trombosit. Karena penelitian ini korelasional jumlah sampel minimum 30 sampel. Data dianalisis dengan uji Spearman correlation test.

\section{HASIL PENELITIAN}

Untuk mengumpulkan seluruh data penelitian diperlukan waktu satu bulan, yaitu periode awal bulan sampai akhir November 2011. Selama kurun waktu satu bulan tersebut terdapat 20 sampel penderita diabetes melitus dengan kaki diabetes dan 20 sampel kelompok kontrol yang sesuai kriteria inklusi. Karakteristik pasien meliputi rerata umur, jenis kelamin, riwayat penyakit diabetes mellitus, dan riwayat penyakit dengan kaki diabetik.

Hasil usia rata-rata subjek laki-laki pada kelompok kasus berumur (43-70) 57,1 tahun. Pada subjek perempuan rata-rata usianya (43-71) 57,9 tahun, sedangkan pada kelompok kontrol subjek laki-laki usia rata-ratanya (52-71) 60,7 tahun dan pada subjek perempuan (51-69) 56,6 tahun.

Tabel 1. Distribusi Sampel Jumlah Trombosit

\begin{tabular}{cccc}
\hline Kelompok & Kasus & Kontrol & Jumlah \\
\hline Meningkat & 6 & 0 & 6 \\
\hline Normal & 14 & 20 & 34 \\
\hline Menurun & 0 & 0 & 0 \\
\hline Total & 20 & 20 & 40 \\
\hline
\end{tabular}

Tabel diatas menunjukan pada kelompok kasus terdapat 6 orang yang angka trombositnya meningkat dan 14 orang angka trombositnya normal, sedangkan pada kelompok kontrol rerata angka trombosit masih normal dimana 20 orang angka trombositnya normal.

Kemudian dilakukan uji statistik normalitas dengan menggunakan Kolmogorov-Smirnov uji normalitas untuk kelompok kasus uji kolmogorov-smirnov nilai p 0.715 dan kelompok kontrol didapatkan nilai 0,455 yang artinya kedua kelompok berdistribusi normal karena nilai $\mathrm{p}>0,05$. Karena hasil uji nilai berdistribusi normal dilanjutkan dengan uji Mann Whitney U-test, didapatkan nilai p 0,017 hal ini menunjukan bahwa hasil penelitian perbedaan rata-rata angka trombosit pada kedua kelompok bermakna secara statistika karena $\mathrm{p}<0,05$.

Rerata angka trombosit pada kelompok kasus 368250,00/ $\mathrm{mm}^{3}$ sedangkan rata-rata pada kelompok kontrol adalah $275350,00 / \mathrm{mm}^{3}$. Perbedaan antara kedua kelompok tersebut sebesar $92900,00 / \mathrm{mm}^{3}$. Hasil ini dari uji nonparametic test (hypothesis test summary) rerata angka trombosit didapatkan dari report kadar 
trombosit. Maka didapatkan nilai p 0,017 hal ini menunjukan perbedaan rerata angka trombosit pada kedua kelompok bermakna secara statistika dikarenakan nilai $\mathrm{p}<0,05$.

\begin{tabular}{ccc}
\hline Tabel 2. Hasil & Coefficient & Sig. (2-tailed) \\
Uji Statistik & & \\
Spearman & & \\
Correlation & & \\
\hline $\begin{array}{c}\text { Spearman } \\
\text { correlation test }\end{array}$ & $-0,381$ & 0,015 \\
\hline
\end{tabular}

Dari hasil uji statistik Spearman Correlation didapatkan hasil dari koefisien -0,381 dan p value (Sig. (2-tailed) 0,015. Hal ini menunjukkan bahwa secara statistik terdapat hubungan antara angka trombosit dengan kejadian kaki diabetik pada penderita diabetes melitus tipe II, karena hasil dari uji statistik spearman correlation nilai $\mathrm{p}<0,05$ yang artinya secara statistik bermakna.

\section{BAHASAN}

Pada diabetes melitus dapat terjadi peningkatan aktivitas koagulasi menyebabkan hiperkoagulasi dengan aktivasi trombosit yang bersifat kronik, dan penurunan fibrinolisis. Trombosit memainkan peran integral dalam hubungan antara fungsi pembuluh darah dan trombosis, kelainan dalam biologis trombosit tidak hanya meningkatkan atrelosklerosis tetapi juga mempengaruhi akibat dari gangguan plak dan artherotrombosis. Di dalam sel endotel trombosit menyerap glukosa yang tidak terkendali kondisi hiperglikemia dan menghasilkan tekanan oksidatif. $^{7}$ Akibatnya, agregrasi trombosit ditingkatkan pada pasien dengan diabetes. Perubahanperubahan pada sel endotel akan menyebabkan produksi tissue factor (TF), substansi prokoagulan utama yang ditemukan diplak atrelosklerosis, juga berhubungan dengan aktivasi dan agregasi trombosit. $^{8}$

Penelitian ini mendapatkan hasil jumlah rerata kadar trombosit dalam batas normal tapi jumlah kuantitasnya lebih tinggi. Hal ini menunjukan bahwa diduga trombosit memainkan peranan penting dalam hubungan fungsi pembuluh darah dan trombosis dimana terjadi peningkatan agregrasi trombosit yang di duga terjadi karena trombosit teraktivasi karena kadar gula darah yang semakin tinggi mengakibatkan beban kepada jaringan tubuh. Penumpukan gula darah tersebut akan mengganggu fungsi pembuluh darah dan sel saraf, rusaknya pembuluh darah yang menyebabkan trombosis kemudian menjadi trombus.

Pada penderita diabetes melitus dengan kaki diabetik dari hasil penelitian ini mendapatkan hasil angka rerata trombosit kelompok kasus dengan kaki diabetik lebih tinggi dari kelompok kontrol. Hasil uji kolerasi didapatkan hubungan yang bermakna peningkatan kadar trombosit dengan kejadian kaki diabetik pada penderita diabetes mellitus tipe II dimana nilai value $(p<0,05)$. Untuk memastikan peran trombosit pada kaki diabetik dilakukan pemeriksaan lanjutan agregrasi trombosit.

\section{SIMPULAN}

Dari hasil penelitian ini dapat ditarik kesimpulan, jumlah trombosit dalam batas normal tetapi terdapat perbedaan rerata angka trombosit kedua kelompok, dimana kelompok dengan kaki diabetik lebih tinggi dari kelompok diabetes melitus tanpa ulkus diabetik. Dan didapatkan hubungan yang bermakna secara statistik peningkatan kadar trombosit dengan kejadian kaki diabetik.

\section{DAFTAR PUSTAKA}

1. Schteingart D. Pankreas Metabolisme Glukosa dan Diabetes Melitus. Dalam : Price S A, Wilson M L, Patofisiologi Konsep Klinis ProsesProses Penyakit, Edisi Ke Enam. Volume 2. Jakarta : EGC, 2008; 1259-61

2. Perkumpulan Endokrinologi Indonesia, 2011. Konsensus Pengelolaan Dan Pencegahan Diabetes Mellitus Tipe II di Indonesia. Perkeni, Jakarta

3. Suryono S, Diabetes Melitus Di Indonesia. Dalam: Sudoyo A, Setiyohadi B, 
Jurnal e-Clinic (eCl), Volume 3, Nomor 1, Januari-April 2015

Alwi I, Simadibrata M, Setiati S. Buku Ajar Ilmu Penyakit Dalam Edisi V. Jilid III. Jakarta: Balai Penerbit FKUI, 2009; 1875

4. Waspadji S. Diabetes Mellitus. Dalam : Noer SM. Buku Ajar Ilmu Penyakit Dalam. Edisi V. Jilid III. Jakarta : Balai Penerbit FKUI, 2009; 1962

5. Tambunan M, Gultom Y. Perawatan Kaki Diabetes. Buku Ajar Penatalaksanaan Diabetes Melitus Terpadu. Balai Penerbit FKUI, Edisi II. 2013; 321

6. Setiabudy DS. Hemostasis Dan Trombosit. FKUI, Edisi IV. 2009; 45
7. Clark N, Peripheral Arterial Disease in People With Diabetes. American Diabetes Assosiation. 2003 http://care.diabetesjournals.org/conte nt/26/12/3333.full. diakses tanggal 28 Desember 2012

8. Putra RGP, Widyamoko A. Hubungan Kadar Trombosit Dengan Kejadian Peripheral Arterial Disease Pada Penderita Diabetes Melitus Tipe 2 [jurnal]. 2009. Yogyakarta: Fakultas Kedokteran Universitas Muhammadiyah. 